\title{
Dampak Perkembangan Pariwisata Terhadap Kondisi Sosial Ekonomi Masyarakat Di Pulau Nusa Lembongan
}

Budi Shantika a,1, I Gusti Agung Oka Mahaggangaa, 2

${ }^{1}$ budishantikaelf@gmail.com, ${ }^{2}$ okamahagangga@unud.ac.id

a Program Studi S1 Destinasi Pariwisata, Fakultas Pariwisata,Universitas Udayana, Jl. Dr. R. Goris, Denpasar, Bali 80232 Indonesia

\begin{abstract}
This research was conducted based on the condition of the development of tourism on the island of Nusa Lembongan, aiming to find out the impact brought about by socio-economic conditions against the tourism society.This study uses qualitative and quantitative approach with mix method, the primary data source that are obtained by observations and direct interviews and secondary data. The sampling technique used was purposive sampling techniques and data analysis using the method of case study. This study shows tourism provides impact on society and the government on the island of Nusa Lembongan are seen from eight aspect among others : impact increasing of foreign exchange, impact toward local community income that increasing before tourism exist, impact toward higher prices than the real prices, impact toward employment for opportunity to local community, ownership and control of tourism accommodation, the distribution of benefits and advantage against indigenous village, development in general are seen from $4 A$ tourism and government income of tax viewed from PHR. Advice can be given to government and businessman and tourism service on the island of Nusa Lembongan in the order of future improve the facilities, infrastructure supporting tourism, reinforce the rules on the division of the proceeds against the indigenous villages, improving access and employment for local community on the island of Nusa Lembongan.
\end{abstract}

Key Words : Tourism, Nusa Lembongan Island, Impact

\section{PENDAHULUAN}

Pariwisata adalah pergerakan manusia yang bersifat sementara ke tujuan-tujuan wisata yang berada diluar tempat kerja dan tempat tinggalnya sehari-hari dimana aktivitas dilaksanakan selama tinggal dalam daerah tujuan wisata dan disediakannya fasilitasfasilitas untuk memenuhi kebutuhan mereka (Mathieson and Wall, 1982 dalam Bharuna 2009).

Kunjungan wisatawan di suatu daerah pariwisata menyebabkan adanya interaksi sosial antara masyarakat disekitarnya yang menyebabkan perubahan pola atau tata cara hidup masyarakat lokal (Sidarta 2002). Kegiatan pariwisata yang berkembang akan memberikan dampak baik secara langsung atau secara tidak langsung terhadap kehidupan sosial dan perekonomian masyarakat disekitarnya. Meningkatnya kebutuhan manusia untuk melakukan perjalanan wisata menyebabkan pariwisata sebagai salah satu sektor perekonomian yang menjanjikan dimata masyarakat. Sehingga tidak sedikit masyarakat lokal khususnya yang berada di kawasan pariwisata cenderung meninggalkan mata pencaharian sebelumnya untuk beralih menjadi pekerja pariwisata.

Bali merupakan destinasi pariwisata internasional yang menjadi barometer pariwisata Indonesia dan setiap tahunnya selalu mendatangkan wisatawan dengan jumlah yang cukup banyak, baik wisatawan mancanegara maupun wisatawan nusantara. Jumlah kunjungan wisatawan ke Bali mengalami peningkatan setiap tahunnya dari tahun 2012 sampai dengan tahun 2016, dengan total kunjungan sebesar 18.867 .027 wisatawan mancanegara dan 35.796.801 wisatawan nusantara (Dinas Pariwisata Provinsi Bali Tahun 2017).

Peningkatan kunjungan wisatawan tersebut mendorong masyarakat dan pemerintah daerah untuk membangun pariwisata kearah yang lebih baik. Pertumbuhan pariwisata di Bali selain pada kawasan pegunungan juga berkembang pesat pada kawasan pesisir. Salah satunya adalah kawasan Nusa Penida yang terletak di Kabupaten Klungkung.

Kecamatan Nusa Penida merupakan salah satu dari empat kecamatan di Kabupaten Klungkung yang terdiri dari Pulau Nusa Penida, Pulau Nusa Lembongan dan Pulau Nusa Ceningan. Pulau Nusa Lembongan merupakan pulau terbesar kedua setelah Pulau Nusa Penida dengan potensi sumber daya atau potensi wisata yaitu hutan bakau (mangrove), karang pantai (clif) di pesisir barat Nusa Lembongan (dream beach), budi daya rumput laut, wisata bahari dan ketersediaan fasilitas- 
Vol. 0 No 0,0000

fasilitas kepariwisataan (akomodasi, insfrastruktur \& suprastruktur).

Nusa Lembongan merupakan salah satu pulau kecil di Bali yang perekonomiannya bersumber dari sektor pariwisata, maka berdasarkan hal tersebut, kajian tentang perkembangan pariwisata disuatu kawasan pariwisata sangat penting untuk mengetahui sejauh mana dampak yang ditimbulkan.

\section{TINJAUAN PUSTAKA}

Dalam penelitian ini, diambil beberapa acuan dari penelitian sebelumnya yang memiliki kesamaan fokus penelitian dan lokasi penelitian. Hasil penelitian sebelumnya dari I Nengah Subadra dan Nyoman Mastiani Nadra (2006) dalam Jurnal Manajamen Pariwisata Volume 5, Nomor 1 dengan judul "Dampak Ekonomi, Sosial-Budaya dan Lingkungan Pengembangan Desa Wisata di Jatiluwih Tabanan". Hasil dari analisis penelitian tersebut perkembangan pariwisata di objek daya tarik wisata Jatiluwih yang difokuskan pada pariwisata berkelanjutan dilihat dari tiga aspek utama yaitu aspek ekonomi, sosial-budaya dan lingkungan dengan melakukan penataan kawasan objek wisata.

Penelitian selanjutnya dari I Ketut Suja dan I Putu Budiarta (2015) dalam Jurnal Sosial dan Humaniora Politeknik Negeri Bali Vol. 5, No.1 Maret 2015 dengan judul "Total Economic Value Destinasi Wisata Nusa Lembongan Dalam Pembangunan Pariwisata Berkelanjutan Berwawasan Lingkungan". Hasil penelitian tersebut yaitu peningkatan jumlah kunjungan wisatawan setiap tahunnya dengan nilai ekonomi total di Pulau Nusa Lembongan sebesar Rp.722.181.418,00 yang akan dipengaruhi oleh keadaan dan fungsi dari tujuan wisata, sehingga nilainya bisa meningkat atau menurun.

Penelitian ini menggunakan beberapa konsep analisis yang digunakan untuk mengalisis data yang ada dilapanagan. Adapun konsep yang digunakan yaitu, konsep dampak pariwisata (Paramitasari, 2010), konsep sosial ekonomi (Oktama 2013), konsep dampak sosial ekonomi (Cohen dalam Pitana, 2005) dan konsep masyarakat lokal (Koentjaraningrat, 2005).

\section{METODE}

Penelitian ini dilakukan di Pulau Nusa Lembongan, Kecamatan Nusa Penida,
Kabupaten Klungkung. Adapun ruang lingkup yang digunakan untuk membatasi penelitian ini adalah dampak pariwisata terhadap kondisi sosial ekonomi masyarakat di Pulau Nusa Lembongan dilihat dari:

a. Dampak pariwisata terhadap pendapatan masyarakat di Pulau Nusa Lembongan

b. Dampak terhadap kesempatan kerja bagi masyarakat di Pulau Nusa Lembongan

c. Dampak terhadap harga-harga kebutuhan pokok di Pulau Nusa Lembongan

d. Dampak terhadap distribusi manfaat/keuntungan bagi Desa Adat dan masyarakat di Pulau Nusa Lembongan

e. Dampak terhadap kepemilikan dan control akomodasi pariwisata di Pulau Nusa Lembongan

f. Dampak terhadap pembangunan pada umumnya dilihat dari 4A di Pulau Nusa Lembongan.

Jenis dan sumber data dalam penelitian ini menggunakan jenis data kualitatif (Slat, 2013), berupa hasil wawancara yang dituangkan dalam penulisan deskriptif dan gambaran umum lokasi penelitian. Jenis data kuantitatif (Kusmayadi, 2000) dalam penelitian ini berupa data jumlah kunjungan wisatawan ke Pulau Bali dan Kabupaten Klungkung, data jumlah sebaran penduduk di Pulau Nusa Lembongan dan data akomodasi yang ada di Pulau Nusa Lembongan serta dua sumber data yaitu data primer dan data sekunder (Moleong 2005).

Teknik pengumpulan data yang digunakan yaitu ada tiga : obervasi (Sugiyono, 2012), wawancara (Bungin, 2007) dan kepustakaan (Suwintari, 2012). Untuk menentukan informan dalam penelitian ini yaitu menggunakan teknik purposive sampling. Purposive sampling adalah teknik penentuan informan dengan pertimbangan tertentu, yang terlebih dahulu ditentukan oleh peneliti sesuai dengan status serta kepentingan penelitian (Sugiyono 2010).

Teknik analisis data dalam penelitian ini yaitu menggunakan teknik analisis data deskriptif kualitatif dengan melakukan langkahlangkah sebagai berikut: pengumpulan data, reduksi data, penyajian data dan verifikasi atau penarikan kesimpulan (Moleong 2005). 
Vol. 0 No 0,0000

\section{HASIL DAN PEMBAHASAN}

Pesatnya perkembangan pariwisata di Nusa Lembongan memberikan alternatif lain bagi mata pencaharian utama masyarakat di Nusa Lembongan sehingga mampu mengurangi angka kemiskinan diwilayah tersebut. Dampak postif pariwisata terhadap kondisi perekonomian menurut Leiper (dalam Nurhidayati 2011) yaitu penyerapan tenaga kerja, individu yang menggantungkan hidupnya dari sektor pariwisata, pendapatan dari usaha jasa pariwisata, multiplier effect kegiatan ekonomi pariwisata terhadap kegiatan ekonomi keseluruhan disuatu wilayah, pemanfaatan fasilitas pariwisata oleh masyarakat lokal, penciptaan lapangan kerja dan perencanaan daya tarik wisata yang dapat dikembangkan di wilayahnya.

Tingkat kepadatan penduduk di Pulau Nusa Lembongan yaitu 705 jiwa $/ \mathrm{km}^{2}$ yang tersebar di dua desa yaitu Desa Jungutbatu dan Desa Lembongan (Dinas Kependudukan dan Catatan Sipil Kabupaten Klungkung tahun 2016)

Perkembangan pariwisata di Pulau Nusa Lembongan tentunya memberikan dampak baik dampak positif maupun dampak negatif terhadap masyarakat lokal seperti peningkatan taraf perekonomian masyarakat, perubahan mata pencaharian, pendidikan dan lain sebagainya. Adapun dampak yang timbulkan oleh perkembangan pariwisata di Pulau Nusa Lembongan terhadap kondisi sosial ekonomi masyarakat di Pulau Nusa Lembongan adalah sebagai berikut:

a. Dampak terhadap pendapatan masyarakat di Pulau Nusa Lembongan

Pariwisata yang berkembang di Pulau Nusa Lembongan sampai saat ini masih belum merata menyebabkan terjadinya kesenjangan terhadap pendapatan masyarakatnya. Hal tersebut disebabkan, perkembangan pariwisata yang terjadi hanya dikawasan pesisir dan atraksi pariwisata yang masih terbatas, sehingga tidak sedikit masyarakat yang berada di bagian tengah pulau belum merasakan keuntungan pariwisata secara signifikan. Sebelum ada pariwisata di Pulau Nusa Lembongan masyarakat lokal dengan mayoritas sebagai petani rumput laut dan nelayan dengan pendapatan sebagai petani rumput laut Rp.1.000.000 sampai Rp.2.000.000 dalam sekali panen, sedangkan untuk buruh pengikat rumput laut dengan penghasilan Rp.900.000 sampat Rp.1.000.000 setiap kali panen dengan upah Rp. 4.500 per ikat dengan berat 1 kilogram dan setiap kali panen seorang buruh biasanya mengikat sampai 200 kilogram.

Sedangkan setelah adanya pariwisata, masyarakat lebih memilih menjadi pekerja pariwisata dibandingkan menjadi petani rumput laut atau nelayan yang tentunya dengan penghasilan yang lebih besar dari sebelumnya. Masyarakat yang bekerja menjadi pekerja pariwisata mendapatkan penghasilan sesuai dengan UMK Kabupaten Klungkung yaitu sebesar Rp.1.991.529 dengan service yang didapat setiap bulannya yang bias mencapai Rp.4.000.000 sampai Rp.5.000.000 setiap bulannya. Namun, masyarakat yang tidak bekerja di sektor pariwisata yang kebanyakn berusia diatas 60 tahun bekerja sebagai buruh bangunan, penjual cindera mata atau nelayan ikan biasanya berpengasilan Rp.400.000 dalam satu minggu.

b. Dampak terhadap kesempatan kerja

Sebelum ada pariwisata di Pulau Nusa Lembongan, mayoritas masyarakat lokal bekerja sebagai pateni rumput laut, nelayan dan buruh bangunan, sedangkan setelah ada pariwisata kesempatan kerja bagi masyarakat lebih beragam, mulai dari waiter/waitress direstoran atau bar, bekerja di hotel atau villa, membuka usaha homestay dan penginapan, usaha transportasi seperti penyewaan sepeda motor, pekerja di speedboat atau kapal angkut, membuka usaha warung, restoran atau toko, tour guide, pelatih surfing dan dive serta pekerjaan di bidang pariwisata lainnya.

Kesempatan kerja setelah adanya pariwisata di Nusa Lembongan lebih besar peluangnya bagi masyarakat dengan umur produktif yaitu 18-50 tahun, dengan pakerjaan sebagai karyawan hotel, restoran, jasa transportasi dan pekerjaan di sector pariwisata lainnya. Sedangkan bagi masyarakat dengan usia lanjut harus mencari pekerjaan lainnya yang dapat membantu perekonomiannya, seperti buruh bangunan, pedangang souvenir, 
usaha warung dan penyedia sampan untuk kebutuhan pariwisata.

c. Dampak terhadap harga-harga

Dampak yang ditimbulkan pariwisata yang paling dirasakan oleh wisatawan dan masyarakat lokal adalah harga-harga kebutuhan rumah tangga dan harga-harga makanan pokok. Harga makan pokok seperti beras, gula, kopi, rempah-rempah biasanya lebih mahal dua kali lipat dari harga aslinya, seperti harga beras 1 kilogram dengan harga Rp.10.500 di Pulau Nusa Lembongan dijual dengan harga Rp.21.000, minuman kaleng dengan harga Rp.8.000 dijual dengan harga Rp.12.000.

Sulitnya mendapatkan persediaan makanan dan minuman kemasan disebabkan oleh terlalu banyaknya pemilik usaha warung atau toko, sedangkan jumlah pengepul yang menyediakan persediaan makanan dan minuman kemasan di Nusa Lembongan terbatas. Keberadaan pengepul yang terbatas dibarengi dengan sulitnya akses yang harus ditempuh, sedangkan permintaan yang terus meningkat menjadi faktor utama kenaikan harga-harga di Pulau Nusa Lembongan.

Kebutuhan pokok dan makanan tersebut dibeli dari Pulau Bali, biasanya di Pasar Kumbasari atau Pasar Badung oleh pengepul yang kemudian dibawa dari Padang Bai ke Pulau Nusa Penida kemudian diangkut dengan Kapal bermotor ke Pulau Nusa Lembongan.

d. Dampak terhadap distribusi manfaat/keuntungan bagi Desa Adat dan Masyarakat di Pulau Nusa Lembongan

Distribusi manfaat atau keuntungan merupakan pembagian hasil antara investor atau pemilik usaha dan jasa pariwisata kepada masyarakat lokal atau terhadap suatu daerah. Dalam pariwisata, distribusi manfaat atau keuntungan adalah bagaimana pariwisata dapat memberikan keuntungan terhadap pembangunan dan perekonomian didaerah tersebut.

Perkembangan dan pembangunan pariwisata disuatu destinasi pariwisata harusnya memberikan keuntungan bagi seluruh stakeholder yang terlibat. Namun, di Pulau Nusa Lembongan perkembangan pariwisata yang belum terencana dengan matang menyebabkan kurangnya antisipasi Desa Adat dalam pengelolaan pariwisata dikawasannya.

Desa Adat Lembongan dan Desa Adat Jungutbatu sampai saat ini belum menentukan kebijakan terkait distribusi manfaat atau keuntungan dari perusahaan penyedia jasa dan layanan pariwisata di Pulau Nusa Lembongan untuk pembagian hasil dari pihak pengusaha pariwisata kepada Desa Adat, pihak penyedia usaha dan jasa pariwisata sampai saat ini hanya membayarkan pajak dan retribusi kepada pemerintah daerah. Penyedia usaha dan jasa akomodasi seperti hotel, villa, restoran dan resort di Nusa Lembongan membayarkan pajak wajib kepada pemerintah Kabupaten Klungkung yaitu Pajak Hotel, Pajak Restoran dan Pajak Hiburan (PHR).

Sehingga sejauh ini, pihak-pihak pemilik akomodasi pariwisata di Pulau Nusa Lembongan hanya memberikan sumbangan secara sukarela kepada Desa Adat yang waktunya tidak tentu.

e. Dampak terhadap kepemilikan dan kontrol akomodasi pariwisata di Pulau Nusa Lembongan

Dampak pariwisata di Pulau Nusa Lembongan menjadikan Nusa Lembongan sebagai salah satu pasar potensial bagi pelaku usaha dan jasa pariwisata untuk membangun pariwisata di kawasan tersebut. Akomodasi pariwisata di Pulau Nusa Lembongan saat ini 85\% merupakan milik masyarakat lokal, seperti homestay, penginapan, bungalow, warung, toko, restoran dan bar. Sedangkan 15\% merupakan milik investor Indonesia ataupun investor asing.

f. Dampak terhadap pembangunan pada umumnya

Perkembangan dan pembangunan pariwisata di Pulau Nusa Lembongan membawa dampak positif terhadap pembangunan fasilitas penunjang pariwisata, kelembagaan pariwisata, aksesbilitas dan atraksi pariwisata.

1. Attraction (ataraksi)

Atraksi pariwisata di Pulau Nusa Lembongan sampai saat ini masih sangat terbatas. Selama ini, sebagian besar wisatawan yang berkunjung ke Pulau Nusa Lembongan biasanya untuk menikmati keindahan pantai dan 
keanekaragaman bahari, wisata alam atau untuk sekedar mencari ketenangan. Daya tarik wisata yang biasanya ramai dikunjungi wisatawan di Pulau Nusa Lembongan yaitu jungutbatu, songlambung, tanjung sangiang, pemuntalan, batu belek (devil tears), underground house (goa galagala), mangrove point (diving \& snorkeling spot), blue corner (diving, mola-mola \& manta spot) dan shipwreck \& lembongan bai (diving spot).

Atraksi wisata dan destinasi pariwisata di Pulau Nusa Lembongan sebagain besar dikelola oleh pemilik usaha \& jasa pariwisata yang berasal dari Pulau Nusa Lembongan, seperti objek wisata goa gala-gala (underground house) yang berada dirumah warga sehingga dikelola secara pribadi, mangrove point yang dikelola oleh kelompok penyedia jukung atau perahu kecil yang sekaligus menyewakan alatalat snorkeling.

Sedangkan untuk destinasi wisata pantai, seperti pantai di sepanjang Desa Jungutbatu, pantai songlambung, pantai tanjung sanghyang, pemuntelan tidak dipungut biaya apapun, sedangkan underground house, mangrove point and diving spot, blue corner dan shipwreck wisatawan akan dikenakan biaya masuk atau penyewaan alat menyelam dan speedboat.

2. Accessibility (aksesibilitas)

Akses yang dapat ditempuh menuju ke Pulau Nusa Lembongan yaitu menggunakan Kapal Feri, speedboat dan kapal bermotor dengan jalur penyebrangan dari Padang Bai-Nusa Penida-Nusa Lembongan, Sanur-Nusa Lembongan (Pelabuhan Jungutbatu, Tanjung Sanghyang dan Mushroom Beach).

3. Amenity (amenitas)

Fasilitas-fasilitas

penunjang pariwisata di Pulau Nusa Lembongan juga semakin ditingkatkan seperti fasilitas kesehatan, keuangan, polisi dan satgas pariwisata, rambu-rambu lalu lintas dan penunjuk arah, pelabuhan dan akomodasi pariwisata. Untuk saat ini fasilitas yang tersedia di Pulau Nusa
Lembongan yaitu fasilitas akomodasi (hotel, restoran), fasilitas kesehatan (klinik swasta dan puskesmas), fasilitas keamanan (kantor polisi, satgas) dan fasilitas keuangan dan pebankan (atm dan bank).

4. Ancillary (kelembagaan)

Keberadaan pariwisata di Pulau Nusa Lembongan membuat masyarakat lokal aktif dan ikut serta mengembangkan pariwisata di daerahnya. Dengan adanya pariwisata di Pulau Nusa Lembongan, masyarakat lokal berharap pendapat masyarakat dalam pembangunan pariwisata dapat dipertimbangkan dengan membentuk organisasi atau komunitas pariwisata. Di Pulau Nusa Lembongan saat ini terdapat dua lembaga pariwisata POKDARWIS (Kelompok Sadar Wisata yang terletak di Desa Lembongan yang menaungi empat Banjar Adat atau Dusun yaitu Bajar Kawan, Kanjar Kaja, Banjar Kelod dan Banjar Kangin dan Desa Jungutbatu yang juga menaungi empat Banjar Adat yaitu Banjar Kaja, Banjar Kelod, Banjar Kangin dan Banjar Kawan.

\section{SIMPULAN DAN SARAN}

A. Simpulan

Berdasarkan hasil penelitian tentang dampak pariwisata terhadap masyarakat di Pulau Nusa Lembongan diperoleh hasil penelitian yaitu dampak terhadap pendapatan masyarakat yang menjadi dampak paling besar dari delapan aspek lainnya. Perkembangan pariwisata di Pulau Nusa Lembongan berdampak signifikan terhadap pendapatan masyarakat lokal yaitu sebelum adanya pariwisata masyarakat lokal memiliki pendapatan Rp. 900.000 sampai Rp.2.000.000 perbulannya sedangkan setelah adanya pariwisata pendapatan masyarakat meningkat menjadi Rp. 6.000.000 sampai Rp.8.000.000. Sedangkan untuk dampak yang paling kecil ditimbulkan oleh pariwisata di Pulau Nusa Lembongan yaitu dampak terhadap distribusi manfaat/keuntungan, hal tersebut disebabkan karena kurangnya kebijakan tentang bagi hasil antara pihak investor dan pemilik usaha jasa pariwisata dengan Desa Adat, sehingga keuntungan atau pemasukan bagi Desa Adat tidak dikelola dengan baik. 


\section{B. Saran}

Berdasarkan hasil penelitian yang diperoleh dapat dikemukakan saran-saran sebagai berikut :

1. Saran bagi pemerintah daerah provinsi dan pemerintah kabupaten bersama membangun pariwisata yang lebih baik untuk meningkatkan tingkat kunjungan wisatawan sehingga meningkatkan penerimaan devisa Negara.

2. Persebaran pariwisata di Pulau Nusa Lembongan lebih diperhatikan agar merata dan meningkatkan pendapatan masyarakat.

3. Kesempatan kerja yang lebih memihak kepada masyarakat lokal, sehingga mengurangi tingkat penggangguran di Pulau Nusa Lembongan.

4. Peningkatan aksesbilitas untuk mempermudah masyarakat mendapatkan kebutuhan pokok dan logistik lainnya sehingga tidak berdampak besar terhadap harga-harga makanan/minuman kemasan dan kebutuhan pokok lainnya.

5. Pemerintah dan Desa Adat harus lebih mepertegas peraturan tentang pembangunan akomodasi pariwisata di Nusa Lembongan dan distribusi keuntungan dari investor untuk meningkatkan kesejahteraan Desa Adat.

6. Pemerintah diharapkan lebih memperhatikan pembangunan insprastruktur dan suprasutruktur di Pulau Nusa Lembongan, seperti pembangunan akses jalan, fasilitas penunjang rumah sakit, klinik, perbankan dan kantor pelayanan pariwisata \& masyarakat.

7. Pendapatan pemerintah dari pariwisata yang berasal dari pajak PHR diharapkan dapat dikelola dengan baik untuk membangun pariwisata yang lebih baik di Pulau Nusa Lembongan dan destinasi pariwisata lainnya di Kabupaten Klungkung.

\section{DAFTAR PUSTAKA}

2009. Undang-Undang No.10 Tahun 2009 Tentang Kepariwisataan.

Armiyanti, Ni Putu Nita Novi. Dan Sutarjo, I Ketut Suratha. 2012. Tingkat Produktifitas Budidaya Rumput Laut Pada Perairan Pantai di Kecamatan Nusa Penida Kabupaten Klungkung. Jurnal Hurusan
Pendidikan Geografi Universitas Pendidikan Ganesha Singaraja.

Badan Pengelolaan Keuangan dan Pendapatan Daerah Kabupaten Klungkung. 2017. Data Pendapatan Pariwisata dari Pajak PHR. Kabupaten Klungkung.

Bharuna S, Anak Agung Gde Djaja. 2009. Pola Perencanaan Dan Strategi Pembangunan Wisata Alam Berkelanjutan Serta Berwawasan Lingkungan. Jurnal Bumi Lestari, Volume 9 No.1.

Bungin, Burhan. 2007. Penelitian Kualitatif: Kumunikasi, Ekonomi, Kebijakan Publik dan Ilmu Sosial Lainnya. Jakarta: Putra Grafika.

Dharma, IGB S, Dkk. 2016. Pelatihan Pengolahan Produk Rumput Laut Untuk Mendukung Pengembangan Nusa Lembongan Sebagai Destinasi Wisata. Jurnal Udayana Mengabdi, Volume 15 Nomor 2.

Dinas Kependudukan dan Catatan Sipil Kabupaten Klungkung. 2016. Jumlah dan Sebaran Penduduk di Pulau Nusa Lembongan. Kabupaten Klungkung

Dinas Pariwisata Kabupaten Klungkung. 2016. Jumlah Hotel dan Kamar, Jumalh Restoran di Nusa Lembongan. Kabupaten Klungkung.

Dinas Pariwisata Kabupaten Klungkung. 2016. Peta Wilayah Administrasi Kabupaten Klungkung. Kabupaten Klungkung.

Dinas Pariwisata Provinsi Bali. 2017. Jumlah Penerimaan Devisa dan Kunjungan Wisatawan ke Pulau Bali Tahun 2012-2016.

Koentjaraningrat. 2005. Pengantar Antropilogi - Jilid I. Jakarta: PT Rineka Cipta.

Kusmayadi, Edar Sugiarto. 2000. Metodologi Penelitian dalam Bidang Kepariwisataan. Jakarta: Gramedia Pustaka Utama.

Moleong, Lexy J. 2004. Metodologi Penelitian Kualitatif Edisi Revisi. Bandung: PT. Remaja Rosdakarya.

Oktama, Reddy Zaki. 2013. Pengaruh Kondisi Sosial Ekonomi Terhadap Tingkat Pendidikan Anak Keluarga Nelayan di Kelurahan Sugih Waras, Kecamatan Pemalang, Kabupaten Pemalang Tahun 2013. Skripsi. Fakultas Ilmu Sosial Universitas Negeri Semarang.

Pitana, I Gede. 2005. Pengantar Ilmu Pariwisata. Yogyakarta: Andi Yogyakarta.

Pitana, I Gde Dan Gayatri. 2005. Sosiologi Pariwisata:Kajian Sosiologis Terhadap Struktur, Sistem dan Dampak-Dampak Pariwisata. Yogyakarta: Andi Yogyakarta.

ubadra, I Nengah. Dan Nandra, Nyoman Mastiani. 2006. Dampak Ekonomi, Sosial-Budaya dan Lingkungan Pengembangan Desa Wisata di JatiluwihTabanan. Jurnal Manajamen Pariwisata Volume 5, Nomor 1.

Sidarta, I Wayan Tagel. 2002. Dampak Perkembangan Pariwisata Terhadap Kondisi Lingkungan, Sosial dan Ekonomi Masyarakat (Studi Kasus Kawasan Pariwisata Sanur, Denpasar-Bali). Thesis, 
Vol. 0 No 0,0000

Magister Ilmu Lingkungan Universitas

Diponogoro.

Suja, I Ketut Dan Budiarta, I Putu. 2015. Total Economic Value Destinasi Wisata Nusa Lembongan Dalam Pembangunan Berkelanjutan Berwawasan Lingkungan. Jurnar Sosial dan Humaniora Politeknik Negeri Bali Vol. 5, No.1.

Sugiyono. 2012. Metode Penelitian Kuantitatif Kualitatif dan $R \& D$. Bandung: Alfabeta.

Suwintari, I Gusti Ayu Eka. 2012. Kepuasan Wisatawan Terhadap Kualitas Pelayanan Tourist Information Counters di Jalan Padma Utara, Legian, Kuta. Program Magister Kajian Pariwisata, Pascasarjana. Denpasar: Universitas Udayana. 